Historic, archived document

Do not assume content reflects current scientific knowledge, policies, or practices. 


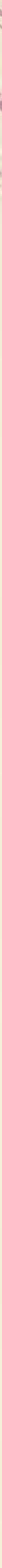

U.S. DEPARTMENT OF AGRICULTURE L E A F L E T No. 197 



\section{POWDERY MILDEW OF ORNAMENTAL PLANTS}

By Freemax Weiss, formerly senior pathologist, Division of Fruit and Vegetable Crops and Diseases, Bureau of Plant Industry

\section{Introduction}

Toward the end of summer many garden flowers, including annualsperennials, and flowering shrubs, develop a dirty-white powdery coating on the leaves. This coating is a fungus growth and is known as mildew. Some of the plants that most frequently show this condition are chrysanthemum, perennial aster, perennial phlox, sunflower, and zinnia. Among flowering shrubs, the rose, lilac, crapemyrtle, and spirea are commonly affected.

The term "mildew" is not only applied to the disease but is also used to designate the fungus, or group of fungi, that cause the disease. For mildews of this sort the name powdery or surface mildew is more precise, as it distinguishes this group from the downy mildews, another group of fungus parasites more widely known on certain vegetables and fruits (cucumber, onion, and grape) than on ornamentals.

\section{The Powdery Mildew Fungus}

In the powdery or surface mildews the white coating forms the regetative and spore-bearing stages and corresponds to the shoot system and fruiting of a higher plant. The vegetative stage of these fungi consists of a mat of branching threads known as mycelium, on which are borne two kinds of microscopic reproductive structures or spores: (1) The summer spores or conidia, which are produced throughout most of the growth period in short columns like a. row of beads, and (2) the winter or resting spores, which are produced toward the end of the growth period within minute capsules. The powdery appearance of the mat is due to the presence of conidia, and the gray or black specks just visible to the naked eye are the resting spore cases. There is also an absorbing system analogous to the roots of higher plants, which consists of microscopic threads or tubes. These penetrate into the leaves of the host plant and extract food therefrom. The mildew is a true parasite and not merely a superficial growth. Because of its parasitic action the host plant is weakened. Heavily mildewed leaves turn yellow and fall prematurely.

There are many kinds of surface mildews. One kind is characteristically found only on rose leaves; another occurs on lilacs; still different kinds occur on apple, crapemyrtle, hazelnut, and willow. One kind occurs on cereals and many grasses. The mildew occurring most commonly on garden flowers belongs to one or the other of the two species Erysiphe cichoracearum or E. polygoni, and these species also occur on a wide range of native plants and weeds including aster, clover, goldenrod, knotweed or smartweed, and ragweed. (The com- 
mon mildews of ornamental plants are listed on p. 4.) It is practically impossible to isolate garden flowers from exposure to these mildews, because the host plants are so numerous and because the vegetative spores, or conidia, of the fungi are so widely distributed by air currents.

\section{Conditions Favorable to Mildew}

As summer wanes the aging of foliage and the decline in growth vigor induce internal conditions in plants that are especially favorable for mildew infection. It is not always the older leaves that are attacked; sometimes, particularly in the mildew of roses and crapemyrtle, succulent young shoots are severely injured. A drastic check in growth activity, such as may be caused by drought, intense heat, or depletion of soil fertility, particularly of nitrogen, also tends to make plants susceptible to mildew.

Besides the internal changes that influence the development of mildew, the environmental conditions that prevail toward the end of summer-for example, high humidity, cooler nights, and frequent heavy dews and foggy mornings-are especially favorable for mildew development and spread. Shady and damp garden sites are especially conducive to mildew, and the disease may develop even in sunny locations if the air circulation is retarded by a wall or hedge, as in a fence corner or adjacent to a building.

A growth of weeds promotes mildew by restricting air circulation and by shading the plants and lowering their vitality through reduction of food and water supplies.

\section{Control}

After mildew has become general enough to be conspicuous, it is usually too late to apply control measures with success, although a change to dry, sunny weather often imposes a natural check. However, ground sulfur, if it is applied in time - that is, at the first appearance of mildew - will not only prevent further spread but will suppress the development of mildew that has started. This form of sulfur, known also as dusting sulfur, or sulfur flour, is a product specially prepared for dusting plants. Stores that handle plants and spray materials generally carry dusting sulfur, but the drug-store product known as flowers of sulfur and intended for household or medicinal use is not suitable for dusting plants effectively. The value of a sulfur preparation for this purpose depends on the smallness of the particles. If they are small enough to pass a sieve having 300 meshes per inch, the material is suitable for dusting.

A dust gun capable of applying a diffuse and uniform coating of powder to both sides of the leaves is the best means of application. A small plunger type of dust gun holding 1 or 2 quarts will suffice for a small garden; such guns are inexpensive and fairly efficient if only occasional use is required and only a small area is to be covered. In large gardens and commercial plantings a duster operating with a fan or bellows is preferable both from the standpoint of efficient application of dust and saving of labor, as the operating motion is easier and there are no idle strokes. A makeshift method of application, such 
as shaking the dust from a cheesecloth bag, is wasteful of dust and inefficient because it fails to coat the under side of the leaves.

The best time to apply sulfur dust is in the late afternoon when the air is still and the temperature is falling. The foliage should be dry in order to obtain uniform coverage. It is not necessary to apply the dust so heavily that a conspicuous coating is left. Sulfur should not be applied to plants when the temperature is near or above $90^{\circ} \mathrm{F}$. because of risk of sulfur-burn injury.

Sulfur dust alone does not flow easily through a duster; it should be mixed with some other material to act as a flux. Hydrated lime, talc, wheat flour, crude kaolin, or arsenate of lead thoroughly mixed with sulfur in the proportion of 1 part to 10 causes the sulfur to flow more easily, producing a lighter, more uniform coating than can be obtained with sulfur alone.

A sulfur spray may also be used. Sulfur dust will not mix with water to form a spray, but specially prepared dry forms of sulfur known as "wettable sulfur" spray materials are available for this purpose. The widely used fungicide lime-sulfur, which is obtainable in both dry and liquid concentrated form, may also be employed, provided it is sufficiently diluted; but its odor is objectionable, it is ruinous to painted surfaces, and it is more likely to cause chemical injury to the foliage than wettable sulfur spray or sulfur dust. The manufacturer's specifications for summer or foliage applications should be followed with each of these materials. Spraying is likely to give better results than dusting on tall shrubs or trees such as lilacs and crapemyrtles, because the air movement may prevent thorough coverage of tall plants from a hand dust gun. The spray coating lasts longer but causes a more conspicuous residue. Dusting gives an effective coating in less time than spraying and is less messy, but it must be repeated more frequently.

Applications of either spray or dust should be repeated at sufficiently close intervals, depending on the frequency of rain and the growth rate of the plants, to keep the foliage coated with fungicide. Ordinarily this will require one or two applications of dust weekly, or one application of spray every 2 weeks.

\section{Elimination of Overwintering Sources}

The surface mildew fungi live over winter mostly in the form of resting spores that mature on the fallen leaves. In a few instances, for example mildews of rose and of crapemyrtle, the fungus also survives on shoots and in buds of the previous year's growth. The collection and burning of infected plants and fallen leaves at the end of the growing season is an indispensable measure in preventing the recurrence of mildew. In the case of the shrubs mentioned, where the fungus also overwinters on the host, pruning of infected parts and spraying during the dormant season with lime-sulfur at the manufacturer's prescribed rate for winter spraying may also be necessary to attain effective control. 


\section{Principal Ornamental Hosts of Common Surface Mildews}

Fungus

Erysiphe cichoracearum DC

Erysiphe lagerstroemiae West

Erysiphe polygoni DC

Microsphaera alni (Wallr.) Wint.

Phyllactinia corylea (Pers.) Karst

\section{Podosphaera oxyacanthae}

(DC.)

$\mathrm{DBy}$

Sphaerotheca pannosa (Wallr.) Lev.

Uncinula necator (Schw.) Burr

Uncinula salicis (DC.) Wint
Host

Calendula.

Centaurea.

Chicory.

Chrysanthemum.

Clematis.

Cosmos.

Dahlia.

Helianthus.

Phlox.

Rudbeckia.

Verbena.

Zinnia.

Crapemyrtle.

Alyssum.

Aquilegia.

Brassica.

Calendula.

Clematis.

Clover.

Dahlia.

Delphinium.

Diervilla.

Lupine.

Peony.

Scabiosa.

Sweetpea.

Vetch.

Verbena.

Alder.

Birch.

Lilac.

Lonicera.

Oak.

Walnut.

Vaccinium.

Ash.

Beech.

Catalpa.

Chestnut.

Crapemyrtle.

Dogwood.

Elm.

Hawthorn.

Hornbean.

Oak.

(Amelanchier.

Apple.

Hawthorn.

$\{$ Pear.

Persimmon.

Plum.

Spirea.

SPeach.

Rose.

Ampelopsis.

Grape.

SPoplar.

\{Willow. 

